\title{
THE DIFFICULTIES OF STUDENTS AT THE SECOND YEAR OF SMA St. THOMAS 3 MEDAN IN TRANSLATING ENGLISH IDIOMS INTO INDONESIAN
}

\author{
Fitri Susi Sinurat \\ State University of Medan \\ fitrisusi964@yahoo.com
}

\begin{abstract}
This study deals with the difficulties of students at the second year of SMA St. Thomas 3 Medan in translating idioms English-Indonesian. The objective of this study is to find out the students' difficulties in translating idioms from English to Indonesian. The sample of this study was the students of class XI IPA-2 SMA St. Thomas 3 Medan. This study used descriptive qualitative research. The data were collected by giving a test which consists of 35 items of English idioms that must be translated to Indonesian. Based on the data analysis, the students' difficulties generally are mostly caused by lacking of vocabularies so they were no able to understand the meaning clearly. Another students' difficulties are in understanding the context of the sentence in each items, guessing the exact meaning of an idiom in the sentence, and also in choosing an appropriate diction to replace the word of an idiom. The result of this study showed that the second year students of SMA St. Thomas 3 Medan have some difficulties in translating idioms from English to Indonesian. They need more teaching about the way of translating and the teacher should give more attention to train the students in translating idioms.
\end{abstract}

Keywords : The Students' Difficulties, Translating English Idioms into Indonesian

\section{INTRODUCTION}

English is one of the languages that is acknowledged as an international language. Most of people in this world use it in communication and make the relationship with people from different part of place and languages in all over the world. Therefore, using English is the easiest way comunication with people from other countries about many aspects in human life such as education, science, business, technology, culture and also another aspects.

Language is a basic part for human's life as a means of communication. It can be spoken or written and it can be also understood by many different system of communication that is used everywhere. Language plays an important role because it is the medium of communication in expressing an idea, emotion, feeling, and thought to other people. By using language people can communicate each other. Language is built by some skills, there are listening, speaking, reading, and writing. All of the language skills support each other, for examples listening for detail, speaking to make a speech, reading for general understanding, and writing to make a note.

Talking about language skills, people normally refer to listening, speaking, reading, and writing. However, there is another important skills that they seem to neglect in language learning, namely translation. J.C.Cattford (1965:20) states that translation may be defined as the replacement of textual material in one language (Source Language) by equivalent textual material in another language (Target Language). Translating is not an easy task because each language has its own rules in phonetic, structure, and words. In translating sometimes the learner finds some 
problems and dealing with the equivalence that he or she cannot find in the target language.

One of translation problems is dealing with idiom. It is also regarded as the one of important aspects in English. Idioms are frequently used in a wide variety of situations. Hornby (1995:589) states that idiom is a phrase or sentence whose meaning is not clear from the meaning of its individual words and which must be learnt as a whole unit. Idioms are used in both oral and written language.

Since idiom is a part of language, it should also be taught along with learning English. In a second language learning classroom, complete an idiom teaching will not usually be offered and required; however, all students must be prepared to meet the challenge of idioms which occur frequently whether in spoken and written English.

However, the fact shows that idiom translation always causes a lot problems to the learners. Based on the writer's experience through training teaching practice (PPL) in SMP N 4 Medan is the writer found some students' problems by learning English in translating idioms from English to Indonesian. The students usually find the difficulties in recognizing and understanding whether it is an idiom or not, and also understanding its exact meaning. Besides that, the students also confused to determine the appropriate diction to replace the word of idiom in a sentence. This shows that idiom translation carries a sense that makes the comprehension of an idiom is difficult.

The theory that the writer used in this translation concept is based on Peter Newmark's theory. Newmark (1988:25) defines the act of translating as transferring the meaning of a text from one language to another, taking care mainly of the functional relevant meaning. He works with three propositions, such as: firstly, the more important the language of a text, the more closely it should be translated; secondly, the less important the language of a text, the less closely it needs to be translated; and thirdly, the better written a text, the more closely it should be translated.

In other case that is related to the facts, the students also complained that learning English is so difficult for whole aspect so that the writer tries to limit and looking for the problem in one skill namely translation skill and then the writer more specifically focuses on the students ability in translating idioms from English to Indonesian. So based on the reason above, the writer has found the problem in translating about an idiom and interested to pick up a research problem.

\section{REVIEW OF LITERATURE}

\subsection{Defenition of Translation}

When people talk about language skills, they normally refer to listening, speaking, reading, and writing. However, there is another important skill that seem to neglect in language learning, namely translation.

To define what translation is, some statements can be presented as follows. Nida and Taber (1969:12) propose that translating consists of reproducing in the receptor language the closest natural equivalent of the source language message, firstly in terms of meaning and secondly in terms of style. In other words, the results of translation should not sound as translation but without changing the meaning of the source language. Wills (1982:112) says that translation is a procedure which leads from a written source language text to an optimally equivalent target language 
text and requires the syntactic, semantic, stylistic, and text pragmatic comprehension by the translator of the original text. Larson (1984:3) says that translation consist of translating the meaning of the source language into the receptor language. This is done by going from the form of the first language to the form of the second language by way of semantic structure." According to Newmark (1988), translation is a craft consisting in the attempt to replace a written message and/or statement in one language by the same message and/or statement in another language.

Based all the defenitions above, the writer concludes that translation is just not transferring of one language to another language but translation is an activity to reconstructing from one language to another language but with the same contents of thought, ideas, or message without add or less the meaning. But in fact, many people cannot translate the language well so the hearers cannot understand what the meaning is.

\subsubsection{Processes of Translation}

Newmark (1988:21) states that translation is a process of transferring a text in the Source Language into an equivalent text in the Target Language. This process is not simply translating each word into Target Language, but it is to look for the equivalence of meaning or message in the Source Language to be transferred into Target Language.

There are some processes of translation namely:

a) Understanding the meaning or message of the text in the source language.

b) Looking for an equivalent meaning or message in the target language.

c) Restricting this equivalent meaning or message in the target language into an accepted form of text in the target language.

Based on the explanation above, it explains that translation as a part of cultural strategy which should not be ignored from educational policy. In translating a text, one has to master some skills such as: grammar, vocabulary, and the background of the original text because each element is very important to be a good translation.

\subsection{Types of Translation}

According to Larson (1984:15), there are two types of translation namely form-based translation and meaning-based translation.

\subsubsection{Form-Based Translation}

Form-based translation attempts to follow the form of the Source Language and is known as literal translation. A literal translation sounds like nonsense and has little communication value. If the two languages (IndonesianEnglish) are related, the literal translation will be understood easier since the general grammatical form maybe similar. However, the literal choices of lexical items make the translation sound foreign.

\subsubsection{Meaning-Based Translation}

Meaning-based translation makes every effort to communicate the meaning of the Source Language text in the natural forms of the receptor language. Such translation is called idiomatic translation. Idiomatic translations use the 
natural forms of the receptor language, both in the grammatical and in the choice of lexical items.

Based on the pupose of translation, Brislin in Choliludin (2006:26), categorizes the translation into four types, namely: pragmatic translation, aestheticpoetic translation, ethnographic translation, and linguistic translation.

1. Pragmatic Translation

Pragmatic translation refers to the translation of a message with an interest in accuracy of the information that is meant to be conveyed in the source language form and it is not concerned with other aspects of the original language version. The clearest example of pragmatic translation is the translation of the information about repairing a machine.

2. Aesthetic-poetic Translation

Aesthetic-poetic translation refers to translation in which the translator takes into account the affect, emotion, and feelings of an original agnate version, the aesthetic form used by the original author, as well as any information in the message. The examples of this type are the translation of sonnet, rhyme, heroic couplet, dramatic dialogue, and novel.

3. Ethnographic Translation

The purpose of ethnographic translation is to explicate the cultural context of the source and target language versions. Translators have to be sensitive to the way words are used and must know how the words fit into cultures. An example is the use of the word 'yes' versus 'yea' in America.

4. Linguistic Translation

This is concerned with equivalent meanings of the constituent morphemes of the source language and grammatical form. The example is language in a computer program and machine translation.

\subsection{Methods of Translation}

The central of translation on whether to translate like rally or freely. This method actually uses in our daily lives. Peter Newmark (1988:45-47) states that there are eight methods of translation. They are elaborated in the following subsections below:

\subsubsection{Word for word Translation}

In this method, the words of the source language text are rendered one by one into the target language without making allowance for grammar. In this method, there is no commuication value. The main use of word for word translation is either to text as a pre translation process in which the SL word order is preserved and the words translated singly by their most common meanings and out of context. Example:

SL : The accident happened in West Kalimantan

TL : Itu kecelakaan terjadi di Barat Kalimantan

\subsubsection{Literal Translation}

This is a kind of translation which attempts to follow the form of the source language text. The source language grammatical constructions are converted to their nearest target language equivalents but the lexical words are again translated singly, out of context. Actually, literal translation has a little communication value and a little help to the readers of the target language. 
Example:

SL : The accident happened in West Kalimantan

TL : Itu kecelakaan terjadi di Kalimantan Barat

\subsubsection{Semantic Translation}

In semantic translation, the content of the message is more emphasized rather than the effect. It attempts to render, as closely as possible, the semantic and syntactic structures of the receptor language. It must convey the precise contextual meaning of the original. In this method the less important cultural words are translated by functional terms not by cultural equivalents.

Example:

SL : "Wet Paint!"

TL : "Cat Basah!"

\subsubsection{Adaptation Translation}

This method is the freest form of translation. It is used mainly for plays (commedies) and poetry. The source language is converted to the target language and the text is rewritten. In adaptation method, the translator adds the excessive information and finally causes a meaning deviation.

Example:

SL : The accident happened in West Kalimantan

TL : Kecelakaan itu telah terjadi di suatu daerah di Kalimantan Barat

\subsubsection{Free Translation}

Free translation reproduces the matter without the matter, or the content without the form of the original text. Usually, it is a paraphrase, much longer than the original, called "intralingual translation".

Example:

SL : The accident happened in West Kalimantan

TL : Kecelakaan itu terjadi di Kalimantan Barat

\subsubsection{Faithful Translation}

A faithful translation attempts to reproduce the precise contextual meaning of the original within the constructions of the target language grammatical structures. It transfers cultural words and preserves the degree of grammatical and lexical in the translation. It attempts to be completely faihful to the intentions and the text realization of the source language writer.

Example:

SL : The accident happened in West Kalimantan

TL : Kecelakaan itu terjadi di Barat Kalimantan

\subsubsection{Idiomatic Translation}

Idiomatic translation makes every effort to communicate the meaning of the source language text in the neutral form of the target language both in the grammatical constructions (syntactic order) and in the choice of the lexical items (semantic). It does not sound like a translation but it is like written originally in the target language. The study of many translations shows that in order to translate idiomatically, a translator will need to give attention towards the structure of the source and target language, the choices of diction, and also the culture context.

Example:

SL : A penny earned is a penny saved

TL : Hemat pangkal kaya 


\subsubsection{Communicative Translation}

Communicative translation attempts to keep the exact contextual meaning of the original in such a way that both content and language are readily acceptable and comprehensible to the readers. It attempts to produce on its readers' effect as close as possible to that obtained on the readers on the original, emphasizes the 'force' rather than the content of the message. It is mainly concerned with the receptors, usually in the context of a language and cultural variety. In other words, the meaning of communicative translation is like a warning.

Example:

SL : Stop firing! He is dying now.

TL : Hentikan tembakan! Dia sekarat.

\subsection{Techniques of Translation}

In communicating through language, one can say the message written or spoken. In face to face communication, it commonly uses spoken language. For this case, the writer takes the written language or text to be analyzed. In text, it can be seen the characteristics, such as in choice of words or terms, the sentence structure, and the text organization. HKBP Nommensen University in its book of Translation 1 (2013:108) states there are some translation techniques as follows:

1. Borrowing

Borrowing is the simplest of all translation methods. It would not event merit discussion in this context if translators did not ocassionally need to use it in order to create a stylistic effect. Borrowing may sound superficially unproblematic, if the target language does not have a word for something, just borrow it from a language that does.

Examples:

English $\quad \underline{\text { Indonesian }}$

atom atom

astronaut astronot

memo memo

2. Calque

A calque is a special kind of borrowing whereby a languages borrow an expression form of another, but then translates literally each of its elements.

Examples:

English Indonesian

monetary crisis krisis moneter

vice president wakil presiden

3. Literal Translation

Literal, or word for word translation is the direct transfer of a source language text. In principle, a literal translation is translating by moving directly the content of source language to receptor language.

Examples:

English

Mary has come

It is raining cats and dog
Indonesian

Mary telah datang

Itu adalah sedang hujan kucing-kucing dan anjing-anjing 


\section{Transposition}

The method called transposition involves replacing one word class with another without changing the meaning of the message. Beside being a special translation procedure, transposition can also be applied within a language.

Examples:

English

product

$\underline{\text { Indonesian }}$

instruction

produk

instruksi

5. Modulation

Modulation is a variation of the form of the message, obtain by a change in the point of view. This change can be justified when translation results in a grammatically correct utterance.

Examples:

English

time is money

he called me "lucky dog" $\underline{\text { Indonesian }}$

waktu itu sangat berharga

dia menyebutku orang yang beruntung

6. Equivalence

Equivalence is the translation of idioms when two languages refer to the same situation in totally different ways.

Examples:

$\begin{array}{ll}\text { English } & \text { Indonesian } \\ \text { ouch! } & \text { aduh! } \\ \text { cock-a-doodle-do } & \text { kukuruyuk }\end{array}$

7. Adaptation

This technique is the extreme limit of translation. It is used in those cases where the typed of situation being referred to by the SL message is unknown in the TL culture. In such cases translators have to create a new situation that can be considered as being equivalent.

Examples:

$\begin{array}{ll}\underline{\text { English }} & \underline{\text { Indonesian }} \\ \text { rating } & \text { rating } \\ \text { power } & \text { power }\end{array}$

\subsection{Principles of Translation}

Sufficient knowledge of the source and target language is needed to produce a good translation and there are basically more things to be taken into account by a translator. For instance: the knowledge of translation principles show what to do and what to leave. Therefore, it can give much help to a translator.

Tyler and McQuire in HKBP Nommensen University in its book of Translation 1 (2013:114) formulate the general principles as the following:

1. Translation presents a perfect transferring of ideas conveyed in the original text

2. The style and way of translation have to have similarities with the original text

3. The translator must have a knowledge of the source language and the target language

4. A translator has to use the form of speech generally used

5. A translator has to avoid translating word by word

6. A translator has to select and arrange the words accurately and properly 
Based on the explanation above, it is concluded that the principles of translation will give some advantages to the translators in analyzing the grammar and meaning of word relationship which are done. Identification of text in cultural context and its circumstance should firstly be conducted.

\subsection{Translation Problems}

According to Ghazala (1995:17), a translation problem is any type of difficulty in the source language (SL) text which may result in an interruption of the translation process, so the translator stops translating to recollect his/her ideas again, or to use dictionaries for looking up meaning of words. This difficulty is mainly categorized due to grammatical, stylistic, and lexical problems.

\subsubsection{Grammatical problems}

Grammatical problems are the result of complicated SL grammar, different TL grammar or different TL word order. Among the most frequent grammatical problems are:

a. The translation of verbs "be, have, and modals."

b. The translation of tenses and articles

c. The translation of adjectives and personal pronouns

d. The translation of nominal, verbal and conditional sentences

\subsubsection{Stylistic problems}

The style, or the way of writing, of a particular SL text may pose different problems for the translator. One of these problems is fronting, in which a word, a phrase or a clause is stated at the beginning of a sentence in an unusual way. For instance, 'suicide he committed' instead of 'he committed suicide'. The purpose behind such a fronting is to emphasize on the fronted word, or to draw attention to its importance to the meaning of the whole sentence. Other stylistic problems may include parallelism, ambiguity, redundancy, and nominalization vs. verbalization.

\subsubsection{Lexical problems}

Lexical problems usually occur when a word or an expression cannot be understood, misunderstood or totally unknown to translators. Synonymy, polysemy, monosemy, collocations, metaphors and idioms are considered as the most common lexical problems (Ghazala, 1995:24).

\subsection{Meaning}

Meaning has an important place in translation, as already been indicated by Nida and Taber that "meaning must be given priority in the translation process, the first thing to do is understand the total meaning of source text". Suryawinata (1989:22) in his book Terjemahan Pengantar Teori dan Praktik classified meaning into lexical, grammatical, textual, contextual or situatiional, and socio cultural.

a. Lexical

Lexical meaning is the meaning that can be found in dictionary, it is referential and precise and has to be considered both outside and within the context.

b. Grammatical

Grammatical meaning is the meaning that is build by the sentence structure. Generally grammar is taken for granted since it seems to be merely a set of arbitrary rules about arrangement, but not rules themselves that seem to have any meaning. 
c. Textual

Textual meaning is the meaning of word that build by the connection with another words in a sentence.

d. Contextual or situational

Contextual or situational meaning is the meaning that is build by the context where the word, phrase, or sentence is used.

e. Socio cultural

Socio cultural meaning is the meaning that is build by the socio cultural that used by the speaker or writer.

\subsection{Defenition of Idiom}

It is important to realize that idioms are not only colloquial expressions as many people believe. They appear in formal style and in slang, in poetry, in the language of Shakespeare and the Bible. According to Jennifer Seidl (1988:121), idioms are the expression of at least two words which cannot be understood literally and which function as a unit semantically. Idioms also can means an expression of which meaning cannot be inferred from the meaning of its part (Mc.Carthy \& O'Dell, 2002:6).

Based on the defenition given above, the writer concludes that idiom is an arrangement of words or phrases which put together that has the particular meaning that something different from the individual word and cannot be literally translated as the usual words. For example, the idiom drive somebody round the bend means make somebody angry or frustrated, but we cannot know this just by looking at the words. Therefore, the best way to understand an idiom is to see it in the context.

\subsubsection{Characteristics of Idiom}

Based on the defenitions that are mentioned above, there are some characteristics of idiom (Abderrahmen Amrani in http://www.academia.edu/6713128/Problems-Faced-by-Students-when-

Translating-Idioms-from-English-into-Arabic.html). They are:

1. The order of the words in an idiom cannot be changed. The way of the words are put together is fixed and they cannot change their place. E.g. "go to rack and ruin" not "go to ruin and rack".

2. The words in an idiom cannot be omitted. We as the users of the language are not permitted to delete some of the words of a particular element. E.g. "shed crocodile tears" not "shed tears".

3. There are no extra words that might be added to an idiom. E.g. "have a narrow escape" not "have a narrow quick escape".

4. No words in an idiom can be replaced by anoher word. E.g. "out of sight, out of mind" not "out of sight, out of heart".

5. The grammatical structures of an idiom cannot also be changed. We have the idiom of "ring the bell" but we do not have "the bell was ringed".

\subsubsection{Types of Idiom}

According to Palmer (1976:98), there are three types of idioms, i.e. phrasal verb, partial idiom, and idiom to idiom. In the following discussion and analysis of types of idioms are presented below:

\subsubsection{Phrasal Verb}

Phrasal verb is a very common type of idiom in English, which includes combination of verb + adverb, verb + preposition, and there also sequence of verb, 
adverb, and preposition. The meaning of those combinations cannot be predicted from the individual verbs and adverbs, and in many cases there is a single verb with the same or a very close meaning.

Example:

SL : "He could not heart break the feeling that something was going to go wrong".

TL : "Dia tidak berhasil remuk hati perasaan bahwa akan ada sesuatu yang tidak benar".

In this case the idiom above is translated into 'remuk hati'. It is combined by two words. Break as a verb means 'to raise your shoulders and then lower them to show that you do not know or care about something' and the word break as a preposition means 'away from a place, at a distance in space or time'. In Indonesia, the expression heart break means "luka yang mendalam". In this case, the translation method that is used by the translator is meaning based translation or in other words called as idiomatic translation.

\subsubsection{Partial Idiom}

Partial idiom is also known as verbal idiom, where one of the words has its usual meaning; the other has a meaning that is peculiar to the particular sequence. Example:

SL : "With the hard feel Elizabeth got to her feet from her chair, and go outside".

TL : "Dengan berat hati Elizabeth bangkit dari kursi yang ia duduki dan pergi keluar".

If the sentence above we translate literally, it will be "mendapatkan sampai kaki", but it sounds meaningless and far from what the writer of the source language text meant. The translator adopts meaning based translation method in translating this idiom so the result of translation is clear and natural based on the context. Therefore, the translator uses the word "bangkit" as the equivalent word of idiom go to her feet.

\subsubsection{Idiom to Idiom}

The translator will be necessary to translate idioms into nonidioms, but sometimes a good idiom is used in the target language if there are idioms which matches to the idioms in the source language. In this case, the translator needs to develop a sensitivity to the use of idiom in the target language and keeps the style of the source language.

Example:

SL : "Then I start meditating every morning on ancient Sanskrit mantra where the teacher gives to all he students with under his breath".

TL : "Kemudian saya mulai melakukan meditasi setiap pagi dengan menggunakan mantra Sansekerta kuno yang diberikan oleh guru kepada semua muridnya dengan pelan”.

If the idiom above is translated literally, it will be meaningless and makes the reader confused about the real meaning so the translator uses the meaning based translation method in order to find the closest natural equivalent meaning of the idiom. According to dictionary, the idiom under his breath means 'to say something 
quietly so that people cannot hear', which in Indonesian means mengatakan sesuatu dengan tenang sehingga tidak terdengar. Thus, it is related with the word of 'pelan'.

Mc.Carthy and O'Dell (2003:06) give another classification to the English idioms types focusing on their possible combinations, as it is shown in the following table :

Table 1. The Classification of English Idioms According to Mc.Carthy and O'Dell (2003:06)

\begin{tabular}{|l|l|l|}
\hline \multicolumn{1}{|c|}{ Form } & \multicolumn{1}{|c|}{ Example } & \multicolumn{1}{c|}{ Meaning } \\
\hline $\begin{array}{l}\text { verb }+ \\
\text { object/complement } \\
\text { (and/or adverbial) }\end{array}$ & $\begin{array}{l}\text { kill two birds with } \\
\text { one stone }\end{array}$ & $\begin{array}{l}\text { produce two useful results } \\
\text { by just doing one action }\end{array}$ \\
\hline prepositional phrase & in the blink of an eye & in an extremely short time \\
\hline Compound & a bone of contention & $\begin{array}{l}\text { something which people } \\
\text { argue and disagree over }\end{array}$ \\
\hline $\begin{array}{l}\text { simile (as + adjective }+ \\
\text { as, or like + noun) }\end{array}$ & as dry as a bone & very dry indeed \\
\hline $\begin{array}{l}\text { binomial (word + and }+ \\
\text { word) }\end{array}$ & rough and ready & $\begin{array}{l}\text { crude and lacking } \\
\text { sophistication }\end{array}$ \\
\hline $\begin{array}{l}\text { trinomial (word + word } \\
+ \text { word) }\end{array}$ & $\begin{array}{l}\text { cool, calm, and } \\
\text { collected }\end{array}$ & $\begin{array}{l}\text { relaxed, in control, not } \\
\text { nervous }\end{array}$ \\
\hline whole clause or sentence & $\begin{array}{l}\text { to cut a long story } \\
\text { short }\end{array}$ & $\begin{array}{l}\text { to tell the main points, not } \\
\text { all the fine details }\end{array}$ \\
\hline
\end{tabular}

\subsection{Problems in Translating Idiom}

The problem in translating an idiom is not about which class an idiom is located (Abderrahmen Amrani in http://www.academia.edu/6713128/ProblemsFaced-by-Students-when-Translating-Idioms-from-English-into-Arabic.html). The main problems in translating idioms are explained as follows:

1. An idiom or fixed expression may have no equivalent in the target language: "the way a language chooses to express or not express various meaning cannot be predicted and only occasionaly matches the way another language chooses to express the same meaning. This means that in one language we may express a given meaning by means of a single word".

2. An idiom may have a similar counterpart in the target language (TL), but its context of use may be different. Backer claims that "the two expressions may have different connotations for instance, or they may or they may not be pragmatically transferable".

3. An idiom may be used in the source text in both its literal and idiom sense at the same time: "unless the target language idiom corresponds to the source language idiom in the form and meaning. The play on idiom cannot be succesfully reproduced in the target text". 


\section{RESEARCH METHOD}

\subsection{Research Design}

This study conducted by using descriptive qualitative method. Best (2002:156) said that qualitative method are those in which the description of observation is not ordinarily expressed in quantitative terms, it is not suggested that numerical measures are never used, but that other means of description are emphasized. In summary, this method uses some description of situations or events to discover the findings without statistic analysis procedure.

Research is not simply gathering the data but it is a process of selecting, organizing, analyzing, interpreting and evaluating the data so that valid statements can be made about some aspects of reality. Therefore, this study focused on analyzing the data in order to find out the students' difficulties in translating idioms from English to Indonesian through the students' result test for generally in doing an idiom translation.

\subsection{Population and Sample}

\subsubsection{Population}

The population of this research focused at the second year students (XI IPA and XI IPS) of SMA St. Thomas 3 at Banteng Street, Sei Sekambing Medan. The writer chose the school because the writer wants to know what are the students' difficulties in translating idioms from English to Indonesian. In the school, XI IPA has three classes and XI IPS has two classes in which each class consists of 30 students. Thus, the total number of population was 150 students.

\subsubsection{Sample}

The sample of this research focused on class XI IPA-2 of SMA St. Thomas 3 Medan. The writer took one class of five class of that school which consists of 30 students. The writer chose this class because the students underwent difficulties in translation skill especially in translating an idiom from English to Indonesian. This subject is chosen because the writer should to find the studens' difficulties in translating idioms and also their problems in doing an idiom translation.

\subsection{Instrument of Collecting the Data}

This research used a test as an instrument to collect the data. The writer used an idiom translation test so that the writer can see the students' difficulties directly. The test gave many contibutions to find out the students' difficulties because the students directly translated the test. The writer gave a test that consists of 35 items of English idioms that must be translated to Indonesian. The writer gave the students 90 minutes to do the test. To make doing translation easier, they were allowed to use a dictionary to help them for finding the difficult words so that they could translate or interprete the meaning of the Source Language with their own words well by seeing the context.

\subsection{Procedure of Collecting the Data}

The data of this study is collected by applying documentary technique because the source of this study is the students' answer sheet in the translation of idioms.

1. The writer gave a brief explanation about what the idiom was and showed some examples of idioms. 
2. The writer gave the students a test and the test was an idiom test.

3. The writer asked the students to translate the idiom test into good Indonesian with their own words and understanding.

4. The students were allowed to open the dictionary if necessary.

5. The time allocation that given to the students was 90 minutes to do the test.

6. After the students finished do the test, the writer collected their answer sheet.

7. At last, the writer checked the students' answer sheet, tried to find out the difficulties, and what made the students difficult in translating the idiom test.

\subsection{Technique of Analyzing the Data}

After collecting the data from the students, the writer analyzed the data which has a relation to the meaning of translation in students' result test. The analysis of the data was based on the students translation answer sheet of idioms from English to Indonesian.

The writer directly saw the way of students' translating based on the the type of translation that is related to the idiom test. The writer also should find out their problems in translating idioms whether from their lack of vocabularies, understanding the context, the lexical of problems, the grammatical of problems, or the choose of a diction. The writer described the errors that the students made in the result test to find out the students' difficulties in translating idioms generally and specifically.

\section{RESEARCH FINDINGS}

After the writer had done the research, collected the data, analyzed the students' result test from 30 students with 35 test items, finally the writer found some kinds of students's difficulties in translating idioms from English to Indonesian. The students ' difficulties had many variations. Generally, each students had the same difficulties with others.

Firstly, the students' difficulties in understanding the context and the meaning of the sentence from the source language into the target language in each items. Secondly, the students' difficulties in guessing or understanding the appropriate meaning at the translation of an idiom in each sentence. Thirdly, the students' difficulties in using of the lexical or choosing a diction that was appropriate to replace the word of an idiom. And fourthly, the causes of translating idioms from English to Indonesian done by students were mostly caused by lacking of vocabularies. They also ignored the context of the sentence given. Thus, they translated the idiom by using a dictionary, as the result they were no able to understand the meaning clearly. For example: all of my advices fell on stony ground by him. Most of the students translated the sentence became (semua nasehat saya terasa di daerah berbatu bagi dia). This translation was wrong because it did not have any relation to the real context. Therefore. it should be (semua nasehat saya diabaikan olehnya).

\section{CONCLUSIONS AND SUGGESTIONS \\ 5.1 Conclusions}

According to Peter Newmark, translation is a process of transferring a text in the Source Language into an equivalent text in the Target Language. After analyzing the data, the writer found out some errors in translating idioms from 
English into Indonesian. From the students' errors, the writer found out the students' difficulties as follows:

1. The students' difficulties generally caused by lacking of vocabularies in translating the idiom from the source language to the target language.

2. The students unability to understand the real context of the idiom in each sentences. Besides that, the choosing of a right diction became their problem for many times in translating idioms.

3. The students are very poor in the translation especially in translating idioms from English into Indonesian.

\subsection{Suggestions}

The result of the findings showed that there were many problems in translating idioms from English into Indonesian. With respect to the result, the following suggestions are offered to :

1. English department students, getting best of translation theory and improve their skill in understanding the translation especially about an idiom.

2. English teachers, it is important to pay more attention to translation especially in translating idioms.

3. The other researchers who are interested in doing a research related to the translation skill, it can be one of the references for them in doing another research about the difficulties of students in translating an idiom.

\section{BIBLIOGRAPHY}

Amrani,Abderrahmen.http://www.academia.edu/6713128/Problems-Faced-by

Students-when-Translating-Idioms-from-English-into

Arabic.html.Accessed on March $25^{\text {th }}, 2015$ at 10.30 a.m.

Best, J.W. (2002). Research in Education. USA: Prentice-Hall.

Choliludin. (2006). The Technique of Making Idiomatic Translation. Bekasi: Kesaint Blanc.

Ghazala, H. (1995). Translation As Problems and Solutions (4th ed). Syria: ELGA Publication.

HKBP Nommensen University. (2013). Translation I. Medan: Fakultas Keguruan dan Ilmu Pendidikan Prodi Bahasa Inggris.

Hornby, A.S. (1995). Oxford Advanced Learner's Dictionary of Current English. New York: Oxford University Press.

J.C. Catford. (1965). A Linguistic Theory of Translation. London: Oxford University Press.

Larson, M. (1984). Meaning-Based Translation. USA: University Press of America. 
KAIROS Elt JOURNAL, Vol. 1, No. 2, August 2017

Copyright@2017, ISSN: 2580-4278

Mc.Carthy \& O’Dell. (2002). English Idioms in Use. Cambridge: Cambridge University Press.

Newmark, Peter. (1988). A Textbook of Translation. London: Prentice-Hall.

Nida and Taber. (1969). The Theory and Practice of Translation. Netherland: E.J Brill.

Palmer, F.R. (1976). Semantic: A New Outline. Melbourne: Cambridge University Press.

Seidl, Jennifer. (1988). English Idioms. New York: Oxford University Press.

Wills, W. (1982). The Science of Translation: Problem and Methods. Gunter Narr Verlag: Tubingen.

Zuchridin, Suryawinata. (1989). Terjemahan: Pengantar Teori dan Praktik. Malang: FBS IKIP Malang. 